\title{
ROZWÓJ TRANSPORTU DROGOWEGO - SZANSE I ZAGROŻENIE DLA ŚRODOWISKA I SPOLECZEŃSTWA
}

\author{
THE DEVELOPMENT OF ROAD TRANSPORT - OPPORTUNITIES \\ AND THREATS TO THE ENVIRONMENT AND SOCIETY
}

\begin{abstract}
Economic development, on the one hand, is realizing because of development of road transport through increased transport work (in the case of commercial vehicles) but on the other hand - economic development is a base of the development of road transport through the development of technology, increasing the income and expectations of societies. These mutual relations generate both, opportunities and threats to the environment and society resulting from the development of road transport.

The purpose of the article is to identify and analyze the opportunities as well as the risks connected with the development of road transport for the environment and society. The analysis covered issues related to environmental protection, supplementing them with technical and social problems. Individual aspects were identified and analyzed within these issues and each time they were classified as an opportunity or a threat. Conclusions were drawn about the direction of road transport development from a social point of view, taking into account the principles of sustainable development.
\end{abstract}

Keywords: road transport, environmental protection, sustainable development JEL classification: Q56, R41

* Akademia Górniczo-Hutnicza w Krakowie; Wydział Zarządzania, Katedra Ekonomii, Finansów i Zarządzania Środowiskiem; mtrela@zarz.agh.edu.pl 


\section{Wprowadzenie}

Transport drogowy towarów, odpowiadając za ok. 5\% polskiego PKB, jest jedną z bardzo istotnych gałęzi gospodarki, decydujących o wielkości wzrostu gospodarczego. Z tego punktu widzenia zjawiskiem jak najbardziej korzystnym jest wzrost pracy transportowej w przypadku ciężkich pojazdów użytkowych. Wzrost ilości zarejestrowanych pojazdów osobowych czy wzrost ilości wozokilometrów w przypadku każdego rodzaju dróg dla tych pojazdów prowadzi z kolei do wzrostu mobilności społeczeństwa i świadczy o osiągnięciu wyższego poziomu rozwoju gospodarczego. Należy jednak pamiętać, że chociaż rozwój transportu drogowego jest niezwykle ważnym elementem realizacji wzrostu i rozwoju gospodarczego, to jednak powoduje także niekorzystne społecznie zjawiska. Zaliczyć tu można nie tylko efekty zewnętrzne związane z emisją zanieczyszczeń, emisją hałasu, kongestią (zatłoczeniem) czy wypadkami drogowymi, ale także zmiany będące następstwem wprowadzania najnowszych technologii i rozwoju pojazdów elektrycznych orazautonomicznych. Biorąc to pod uwagę, można dokonać podziału na dwa obszary analiz rozwoju transportu drogowego - „obszar klasyczny” oraz „obszar innowacyjny”. Do obszaru pierwszego można zaliczyć zagadnienia poruszane już od wielu lat w odniesieniu do transportu drogowego, czyli koszty zewnętrzne generowane przez eksploatację środków transportu drogowego oraz koszty ekonomiczne związane z zakupem i eksploatacją pojazdów zasilanych różnymi rodzajami napędów. Natomiast drugi obszar, nazwany innowacyjnym, związany jest z możliwością wystąpienia pewnych zmian psychologicznych wynikających z wprowadzania pojazdów autonomicznych. Przede wszystkim zmiany te mogą wynikać z budowania przekonania o możliwości zastąpienia decyzji kierowcy algorytmami komputerowymi.

W artykule postanowiono poddać analizie zarówno obszar klasyczny, jak i innowacyjny i na tej podstawie zidentyfikować szanse oraz zagrożenia związane z rozwojem transportu drogowego w Polsce. Wiedza taka może stanowić bazę do podejmowania w przyszłości decyzji dotyczących wspierania poszczególnych kierunków rozwoju tej gałęzi gospodarki.

\section{Obszar ,klasyczny”}

Obszar klasyczny analizowano w kontekście wpływu eksploatacji środków transportu drogowego na powstawanie kosztów zewnętrznych oraz zmiany kosztów zakupu i eksploatacji wynikających z zastosowania różnych technologii napędów. 
Eksploatowanie pojazdów drogowych powoduje powstawanie kosztów zewnętrznych związanych z emisją zanieczyszczeń i hałasu oraz kosztów zewnętrznych wynikających z kongestii oraz wypadków drogowych.

\section{Emisja zanieczyszczeń i koszty z tym związane}

W ramach Unii Europejskiej funkcjonują jednolite sposoby i mechanizmy umożliwiające inwentaryzację emisji zanieczyszczeń z transportu drogowego (COPERT) oraz późniejszą ich wycenę (Handbook on external costs of transport), jednak brak obowiązku wykorzystywania tej metodologii powodował, że raportowanie do statystyk europejskich danych w zakresie emisji zanieczyszczeń z transportu drogowego w Polsce opierało się na metodzie, która została stworzona przez Instytut Transportu Samochodowego w Warszawie (ITS) w latach osiemdziesiątych XX wieku. O ile w tamtym okresie metoda ta w bardzo dobry sposób mogła odzwierciedlać emisje zanieczyszczeń, to po okresie transformacji, kiedy rynek motoryzacyjny w Polsce upodobnił się do rynków rozwiniętych państw europejskich, konstrukcja metody ITS nawet po wprowadzanych modyfikacjach nie umożliwiała uwzględnienia szerokiego spektrum typów eksploatowanych pojazdów, co zwiększało niedokładność wyników otrzymanych przy jej wykorzystaniu. Szansą na zwiększenie dokładności danych przedstawianych w inwentaryzacji emisji z transportu drogowego było więc pojawienie się metodologii COPERT. W 2018 roku Krajowy Ośrodek Bilansowania i Zarządzania Emisjami (KOBiZE) po raz pierwszy sporządził inwentaryzację emisji przy wykorzystaniu właśnie tej metody. Równolegle nad zastosowaniem tej metody pracował Główny Urząd Statystyczny (GUS) i również w 2018 roku przedstawił pierwsze wyniki szacunków emisji z transportu drogowego w Polsce. GUS poszedł jednak „o krok dalej” i wykorzystując metodologię zawartą w Handbook... wyliczył następnie koszty zewnętrzne związane z tą emisją zanieczyszczeń. Można mieć więc nadzieję, że szansanaujednoliceniemetodologii służącej doinwentaryzacji emisjizanieczyszczeń $\mathrm{z}$ transportu drogowego w Polsce z metodologią przyjętą jako podstawowa w Unii Europejskiej zostanie wykorzystana i metoda COPERT będzie na stałe włączona do bazy metod wykorzystywanych w Polsce do raportowania w tym zakresie. Podobnie należy mieć nadzieję, że metoda umożliwiająca wycenę kosztów zewnętrznych (Handbook...) również znajdzie się w bazie podstawowych narzędzi służących do analizy kosztów zewnętrznych transportu w Polsce. Zagrożeniem dla szybkiego stosowania przede wszystkim metody COPERT w sprawozdawczości Polski może być konieczność wypracowania wspólnych i najbardziej wiarygodnych założeń przyjętych do obliczeń, które zaakceptuje zarówno KOBiZE, jak i GUS.

W szczegółowej analizie emisji zanieczyszczeń z transportu drogowego w Polsce uwzględniono związki wskazane w Handbook...: tlenki azotu $\left(\mathrm{NO}_{\mathrm{x}}\right)$, 
niemetalowe lotne związki organicznie (NMVOC), cząstki stałe $\left(\mathrm{PM}_{2,5}\right)$ oraz dwutlenek węgla $\left(\mathrm{CO}_{2}\right)$. Emisję pochodzącą $\mathrm{z}$ transportu drogowego tych związków w Polsce przedstawiono na wykresie 1. Emisji dwutlenku siarki $\left(\mathrm{SO}_{2}\right)$ nie uwzględniono, gdyż zawartość siarki w paliwie w Polsce jest na tak niskim poziomie, że eliminuje to problem z jej istotną emisją.

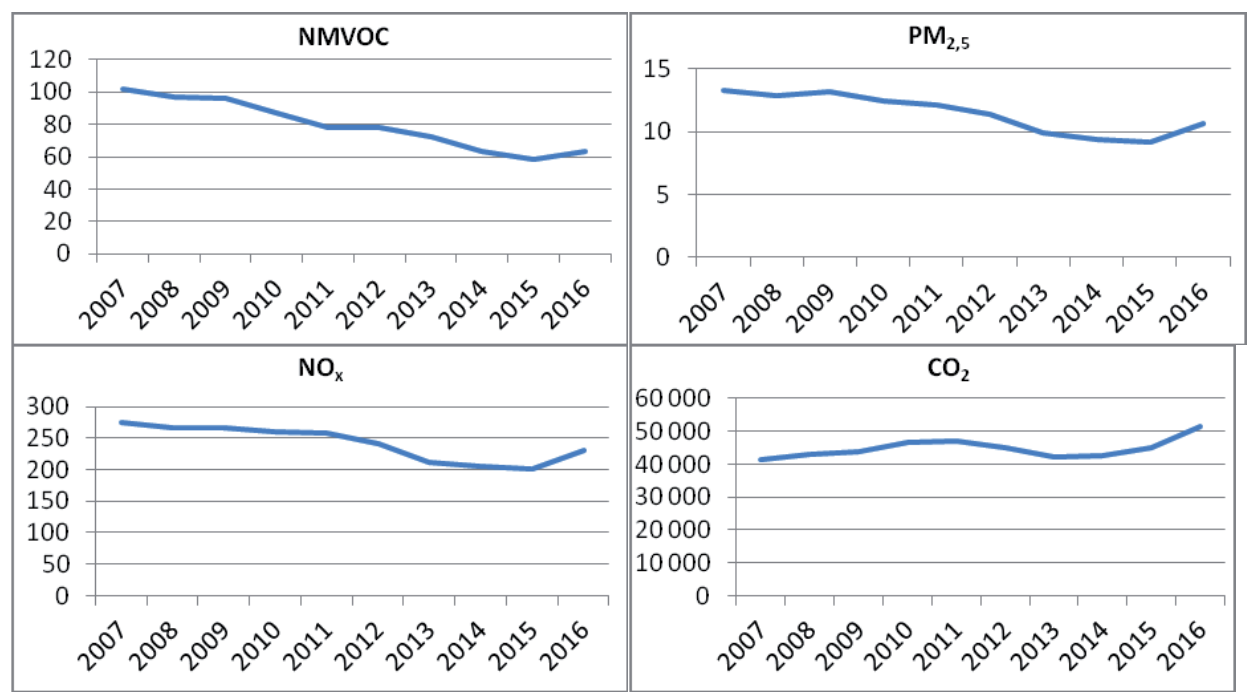

Wykres 1. Emisja zanieczyszczeń z transportu drogowego w Polsce w latach 2007-2016 [tysiące ton]

Źródło: Eurostat

Na podstawie powyższych danych można stwierdzić, że emisja NMVOC, PM2,5 i NOx zmalała w stosunku do 2007 roku, a ponadto wykazywała systematycznie tendencję spadkową aż do 2015 roku. Emisja $\mathrm{CO}_{2}$ w 2016 roku była większa niż w 2007 roku, a istotny wzrost tej wielkości odnotowano od 2014 roku. Aby można było zinterpretować zmiany tych wielkości, należy rozpatrywać je w kontekście zmian ilości zużytego paliwa w transporcie drogowym oraz zmian technologicznych w budowie silników.

Zmiany emisji $\mathrm{CO}_{2}$ mają praktycznie identyczny charakter jak zmiany sumarycznej ilości zużytego paliwa w transporcie drogowym w Polsce (LPG, $\mathrm{ON}$ i PB łącznie). Zależność taka wynika $\mathrm{z}$ faktu, że emisja $\mathrm{CO}_{2}$ jest wprost proporcjonalna do ilości zużytego paliwa i zależy jedynie od jego rodzaju (LPG, ON, PB), a nie od zaawansowania technicznego silnika (norma EURO). Natomiast w przypadku pozostałych zanieczyszczeń, które zależą w dużej mierze od normy ekologicznej spełnianej przez silnik, skutek przyniosło wdrażanie coraz bardziej rygorystycznych norm emisji spalin i to umożliwiło osiągnięcie w 2016 roku emisji mniejszej niż w roku 2007 pomimo wzrostu zużycia paliw, a więc pomimo wzrostu wykonanej pracy przewozowej. Zwraca uwagę jednak nagły 
wzrost emisji NMVOC, PM2,5 i NOx w 2016 roku w stosunku do roku 2015. Wythumaczyć można to względnie dużym w tym okresie tempem wzrostu zużycia wszystkich rodzajów paliw, znacząco większym niż w każdym innym roku $\mathrm{z}$ analizowanego okresu. Spowodowało to, że pomimo sukcesywnego odnawiania taboru samochodowego i zwiększającego się udziału pracy przewozowej wykonywanej przez pojazdy spełniające coraz wyższe normy EURO, nastąpił wzrost emisji zanieczyszczeń w wyniku bardzo znaczącego wzrostu aktywności transportowej. Można zatem powiedzieć, że korzyści z eksploatowania coraz nowocześniejszego taboru były mniejsze niż straty wynikające ze zwiększonej pracy przewozowej. Pozwala to na sformułowanie wniosku, że szansą na ograniczenie emisji zanieczyszczeń jest wprowadzanie nowoczesnych silników spełniających coraz bardziej rygorystyczne normy EURO, jednak nawet pomimo najnowocześniejszych technologii zagrożeniem nadal pozostaje zwiększanie się pracy przewozowej, której zmiany są szczególnie widoczne na rynku przewozów towarów.

\section{Emisja halasu, kongestia i wypadki drogowe}

Zarówno emisja hałasu, kongestia, jak i wypadki drogowe nie zależą w żaden sposób od zaawansowania technologicznego silników i spełniania przez nie bardziej rygorystycznych norm EURO. Bez wątpienia jednak rozwój transportu drogowego objawiający się wzrostem pracy przewozowej należy traktować jako zagrożenie związane ze wzrostem hałasu, kongestii i wypadków drogowych. Należy jednak zauważyć, że rozwój transportu realizowany jest w Polsce również przez wzrost udziału w pracy przewozowej pojazdów najnowocześniejszych technologicznie. To natomiast jednoznacznie należy zakwalifikować jako szansę na zmniejszenie hałasu, co wynika ze wzrostu popularności pojazdów bateryjnych - przede wszystkim hybrydowych, ale także elektrycznych. O ile nie można oczekiwać, że stosowanie nowoczesnych technologii w pojazdach drogowych spowoduje zmniejszenie zatłoczenia, o tyle bez wątpienia jest ono szansą na zmniejszenie ilości i skutków wypadków drogowych, co potwierdzają dane przedstawione na wykresie 2 dotyczące ilości osób zabitych w wypadkach drogowych w Polsce. 


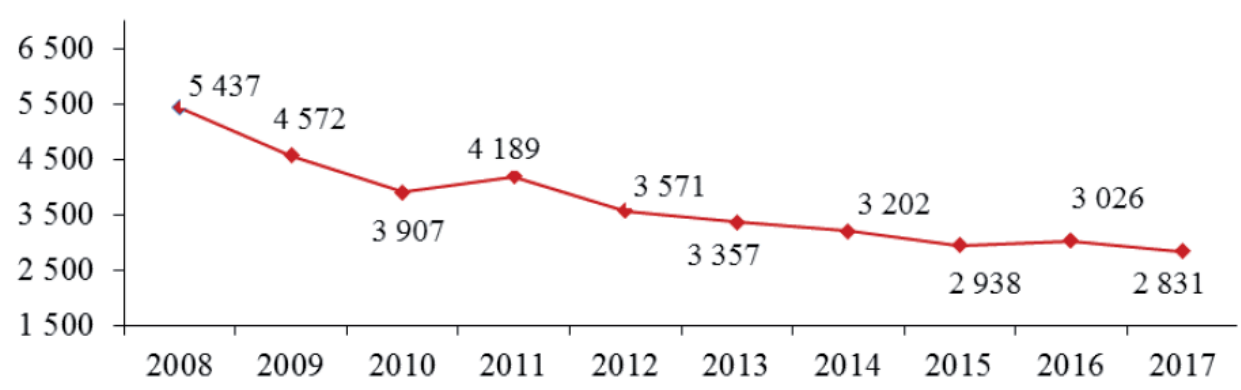

Wykres 2. Liczba zabitych w wypadkach drogowych w Polsce w latach 2008-2017

Źródło: Komenda Główna Policji, Wypadki drogowe w Polsce w 2017 roku

Spadek liczby zabitych osób w wypadkach w części wynika z lepszej infrastruktury drogowej, a w części zawdzięczać go można większemu zaawansowaniu technologicznemu pojazdów. Stosowanie nowoczesnych materiałów w połączeniu z odpowiednim projektowaniem konstrukcji pojazdu powoduje lepszą ochronę kierowcy i pasażerów przed skutkami zderzenia. Dodatkowo elektroniczne układy czuwające nad odpowiednią trakcją pojazdu ograniczają ryzyko zderzenia, a w razie jego wystąpienia bardziej zaawansowane technologicznie systemy poduszek powietrznych minimalizują obrażenia. Rozwój tego typu technologii bez wątpienia należy uznać za szansę na sukcesywne zmniejszanie się śmiertelności w wypadkach komunikacyjnych. Jako zagrożenie w takim kontekście należy uznać podróżowanie z coraz większymi prędkościami, co wynika zarówno z lepszej infrastruktury drogowej, jak i z większego komfortu pojazdów, który powoduje zmniejszenie odczuwania prędkości z jaką porusza się samochód. Zagrożenie to jednak jest niwelowane przez rosnącą świadomość motoryzacyjną kierowców i jednoczesny spadek brawury na polskich drogach.

\section{Zmiana kosztów eksploatacji pojazdów}

Rozwój technologii stosowanej w pojazdach umożliwia zjednej strony ograniczanie emisji zanieczyszczeń i wzrost bezpieczeństwa czynnego i biernego kierowcy oraz pasażerów samochodów, ale z drugiej strony podnosi koszty zakupu pojazdu.

Na przestrzeni ostatnich lat można zaobserwować systematyczny wzrost cen nowych samochodów, gdy porównać ceny następujących po sobie wersji tego samego modelu pojazdu z przybliżoną mocą silnika. Jest to cena technologii, która przejawia się między innymi poprzez mniejszą emisję zanieczyszczeń, większe bezpieczeństwo oraz mniejsze zużycie paliwa. Z finansowego punktu widzenia dla użytkownika istotne jest jednak czy dodatkowe wydatki przy zakupie zwrócą 
się podczas eksploatacji w wyniku mniejszego zużycia paliwa. Niemożliwe jest udzielenie ogólnej odpowiedzi na to pytanie, gdyż każdy model w połączeniu z określonymi założeniami co do użytkowania pojazdu należałoby analizować oddzielnie. Zmniejszenie wydatków na paliwo jest więc szansą wynikającą ze zmian technologicznych na wzrost efektywności finansowej inwestycji, jaką może być zakup samochodu, natomiast jako zagrożenie należy uznać wzrost ceny zakupu pojazdu. Dodatkowo należy wziąć pod uwagę, że technologia służąca zmniejszeniu emisji zanieczyszczeń i zużycia paliwa powoduje zwiększenie skomplikowania pojazdu, a przez to generuje zagrożenie wzrostu ryzyka wystąpienia awarii oraz wzrostu kosztów usunięcia tych awarii. Powyższe zależności występują w przypadku wszystkich konwencjonalnych źródeł napędu pojazdu, a także w przypadku aut hybrydowych. Nieco inaczej może wyglądać sytuacja w przypadku samochodów elektrycznych. O ile zależność między ceną zakupu a ilością zużytego paliwa, w tym przypadku energii elektrycznej, jest analogiczna jak dla samochodów zasilanych konwencjonalnie, to dodatkowej szansy na zmniejszenie kosztów eksploatacyjnych można upatrywać w prostszej, z mechanicznego punktu widzenia, konstrukcji układów napędowych pojazdów elektrycznych, co powinno przełożyć się na zmniejszone ryzyko awarii i mniejsze koszty napraw tych elementów. W odniesieniu do kosztów napraw elementów eksploatacyjnych (głównie elementów układów hamulcowych) należy przyjąć, że w przypadku samochodów hybrydowych i elektrycznych jest szansa na obniżenie tych kosztów, co wynika ze stosowania technologii odzyskiwania energii podczas hamowania pojazdu. Jednocześnie jednak istnieje zagrożenie dla tego rodzaju pojazdów, przede wszystkim elektrycznych, w postaci konieczności wymiany kosztownych akumulatorów gromadzących energię potrzebną do napędu samochodu. Dla wszystkich typów pojazdów istnieje zagrożenie wynikające ze stosowania nowoczesnych technologii w postaci spadku wartości pojazdu (w ujęciu procentowym), tym większego, im bardziej zaawansowane technologie są w nim stosowane, co wynika ze społecznej świadomości konieczności ponoszenia coraz większych wydatków serwisowych na coraz bardziej skomplikowany technologicznie pojazd.

\section{Obszar ,innowacyjny”}

Wraz z rozwojem technologii służących zwiększeniu bezpieczeństwa czynnego i biernego w ostatnim czasie ma miejsce gwałtowny rozwój technologii mających umożliwić autonomiczną jazdę pojazdom samochodowym. Stosowanie algorytmów komputerowych do zastępowania decyzji kierowcy, przy obecnym poziomie rozwoju tych technologii, należy rozpatrywać jako zagrożenie. Wynika to z faktu, że aktualnie żaden producent samochodów nie stosuje technologii tak zaawansowanych, żeby 
bezbłędność ich działania była na poziomie umożliwiającym powierzenie zdrowia i życia komputerowi sterującemu samochodem. Tymczasem zarówno producenci samochodów, jak i media używają bardzo często sformułowań, które przez część społeczeństwa mogą być rozumiane jako potwierdzenie osiągnięcia zaawansowania technologicznego umożliwiającego autonomiczną jazdę samochodom. Pomimo że każdy producent oficjalnie twierdzi, że jego systemy nie mogą aktualnie kierować pojazdem, to jednocześnie prowadzona kampania marketingowa stara się przedstawić pojazd danego producenta jako jak najbardziej zautomatyzowany. Między pojazdem zautomatyzowanym a autonomicznym, $\mathrm{z}$ naukowego punktu widzenia, jest bardzo duża różnica, ale nie każdy kierowca zdaje sobie z tego sprawę. Część z nich nie rozróżnia tych pojęć lub uznaje je za bliskoznaczne. Ale nawet jeśli kierowcy na początku nie do końca będą ufać automatycznym systemom, to i tak świadomość istnienia „komputerowego pomocnika”, który powinien naprawić ewentualny błąd kierowcy, spowoduje zmniejszenie czujności kierowcy, a w niektórych przypadkach zwiększenie brawury. Tymczasem obecnie stosowane technologie w samochodach mogą jedynie pomóc kierowcy w ściśle określonych sytuacjach i najczęściej z dość dużą tolerancją błędu. Nawet podstawowe systemy, które muszą funkcjonować całkowicie bezbłędnie w pojazdach autonomicznych, czyli systemy automatycznego hamowania, chociaż obecne na rynku motoryzacyjnym wiele lat, nadal niejednokrotnie popełniają błędy i nie są w stanie wykryć w odpowiednim momencie przeszkody, aby bezpiecznie przed nią zatrzymać pojazd. To daje tylko obraz bardzo dalekiej drogi, jaką ma motoryzacja do przebycia, aby jakikolwiek samochód można było nazwać autonomicznym. Brak jednoznacznych sygnałów od producentów pojazdów i od mediów dotyczących rzeczywistego miejsca pojazdu na drodze do autonomizacji jest bardzo dużym zagrożeniem. Wraz z upływem czasu kierowcy coraz bardziej będą ufać technologiom, które tak naprawdę nie działają i wszystko wskazuje na to, że jeszcze bardzo długo działać nie będą na wystarczającym poziomie, aby mogły samodzielnie decydować o zdrowiu i życiu człowieka.

Jednocześnie należy zauważyć, że docelowo zastosowanie algorytmów komputerowych w procesie podejmowania decyzji koniecznych do kierowania pojazdem niesie ze sobą bardzo duże szanse na obniżenie kosztów wypadków drogowych, a także na obniżenie kosztów eksploatacji samochodów.

Bardzo trudno stwierdzić, kiedy technologia zostanie rozwinięta do poziomu umożliwiającego dopuszczenie do ruchu pojazdy autonomiczne i czy po dopuszczeniu ich do ruchu rzeczywiście technologia będzie umożliwiać bezpieczne poruszanie się tych pojazdów. Jednak można założyć, że docelowo, choć nie wiadomo kiedy, pojazdy będą mogły być sterowane przez komputer. Wtedy koszty wypadków drogowych powinny się zmniejszyć, gdyż samochody sterowane algorytmami komputerowymi nie będą powodować wypadków drogowych albo w najgorszym wypadku będą powodować mniej wypadków drogowych niż ludzie. 
Dodatkowo, pojazd sterowany przez komputer będzie poruszał się zawsze w powtarzalny, najbardziej efektywny z punktu widzenia wykorzystania energii, sposób. To umożliwi minimalizację zużycia paliwa, bez względu, czy to będzie olej napędowy, benzyna, czy energia elektryczna, co przełoży się na mniejsze koszty eksploatacji i mniejsze koszty zewnętrzne związane z emisją zanieczyszczeń.

Zidentyfikowane w przeprowadzonej analizie szanse i zagrożenia przedstawiono w tabeli 1.

Tabela 1. Szanse i zagrożenia związane z rozwojem transportu drogowego w Polsce

\begin{tabular}{|c|c|}
\hline \multicolumn{2}{|c|}{ OBSZAR „KLASYCZNY” } \\
\hline Szanse & Zagrożenia \\
\hline \multicolumn{2}{|c|}{ Emisja zanieczyszczeń } \\
\hline $\begin{array}{l}\text { Wykorzystanie metodologii COPERT } \\
\text { i Handbook... do ujednolicenia } \\
\text { sprawozdawczości w zakresie inwentaryzacji } \\
\text { emisji i obliczeń kosztów zewnętrznych } \\
\text { transportu, lepsza technologia ograniczająca } \\
\text { zużycie paliwa i emisję } \mathrm{CO}_{2} \text {, lepsza } \\
\text { technologia ograniczająca emisję pozostałych } \\
\text { zanieczyszczeń }\end{array}$ & $\begin{array}{l}\text { Brak jednoznacznie określonych założeń } \\
\text { służących do obliczeń w ramach metodologii } \\
\text { COPERT, większa ilość samochodów, większa } \\
\text { praca transportowa, większa ilość zużytego } \\
\text { paliwa }\end{array}$ \\
\hline \multicolumn{2}{|c|}{ Emisja hałasu, kongestia i wypadki drogowe } \\
\hline $\begin{array}{l}\text { Zmniejszenie hałasu poprzez popularyzację } \\
\text { samochodów bateryjnych, zmniejszenie ilości } \\
\text { rannych i zabitych w wypadkach drogowych } \\
\text { poprzez rozwój technologii w zakresie } \\
\text { bezpieczeństwa czynnego i biernego }\end{array}$ & $\begin{array}{l}\text { Możliwy wzrost średnich prędkości, który } \\
\text { może prowadzić do zmniejszenia korzyści } \\
\text { z rozwoju technologii zwiększających } \\
\text { bezpieczeństwo czynne i bierne }\end{array}$ \\
\hline \multicolumn{2}{|c|}{ Zmiana kosztów eksploatacji pojazdów } \\
\hline $\begin{array}{l}\text { Zmniejszenie kosztów związanych } \\
\text { z wydatkami na paliwo, zmniejszenie } \\
\text { kosztów napraw elementów eksploatacyjnych } \\
\text { w przypadku pojazdów hybrydowych } \\
\text { i elektrycznych, zmniejszenie kosztów napraw } \\
\text { awarii układu napędowego w przypadku } \\
\text { pojazdów elektrycznych }\end{array}$ & $\begin{array}{l}\text { Wzrost ceny zakupu pojazdu, wzrost kosztów } \\
\text { serwisowych związanych z naprawami } \\
\text { wynikającymi ze zużycia elementów } \\
\text { eksploatacyjnych, wzrost ryzyka powstania } \\
\text { awarii, wzrost kosztów napraw awarii, ryzyko } \\
\text { wystąpienia kosztu wymiany akumulatorów } \\
\text { w pojazdach elektrycznych i hybrydowych, } \\
\text { duży spadek wartości pojazdów }\end{array}$ \\
\hline \multicolumn{2}{|c|}{ OBSZAR „INNOWACYJNY” } \\
\hline Szanse (w długim horyzoncie czasowym) & \begin{tabular}{|c|} 
Zagrożenia \\
(w krótkim i średnim horyzoncie czasowym)
\end{tabular} \\
\hline $\begin{array}{l}\text { Najbardziej efektywne wykorzystanie źródła } \\
\text { napędu prowadzące do zminimalizowania } \\
\text { zużycia paliwa i emisji zanieczyszczeń, } \\
\text { osiągnięcie bliskiej zeru liczby osób } \\
\text { poszkodowanych w wypadkach jako } \\
\text { następstwo autonomizacji pojazdów }\end{array}$ & $\begin{array}{l}\text { Wzrost liczby osób rannych i zabitych } \\
\text { w wypadkach na skutek spadku koncentracji } \\
\text { i wzrostu brawury }\end{array}$ \\
\hline
\end{tabular}




\section{Podsumowanie}

W artykule przeanalizowano ogólną sytuację i występujące tendencje na rynku motoryzacyjnym $\mathrm{w}$ Polsce $\mathrm{i}$ na tej podstawie zidentyfikowano szanse oraz zagrożenia, z jakimi należy się zmierzyć w przyszłości. Stanowi to bazę do dalszych badań i analiz, które umożliwią skonstruowanie szczegółowej polityki wspierania rozwoju zrównoważonego transportu drogowego w Polsce.

W ramach przeprowadzonej analizy stwierdzono, że transport drogowy w Polsce rozwija się dynamicznie, zarówno w kontekście wzrostu ilości samochodów osobowych, jak i wzrostu pracy transportowej w przypadku pojazdów użytkowych przy jednoczesnym zmniejszaniu kosztów zewnętrznych emisji zanieczyszczeń (poza emisją $\mathrm{CO}_{2}$ ), co świadczy o postępującym odmładzaniu taboru samochodowego.

Stwierdzono, że wzrost zaawansowania technologicznego pojazdów wynikający z odmładzania taboru jest zjawiskiem korzystnym również z punktu widzenia ilości osób rannych i zabitych w wypadkach drogowych, co obniża koszty zewnętrzne z tym związane. Wzrost popularności samochodów bateryjnych przyczyniał się będzie ponadto do obniżenia kosztów zewnętrznych hałasu.

Rozwój technologii stosowanej w pojazdach drogowych pociąga za sobą dodatkowe koszty w postaci wyższej ceny zakupu i wyższych kosztów serwisowych pojazdu. Możliwe jest jednak jednoczesne zmniejszenie wydatków na paliwo, co w niektórych przypadkach może przewyższać dodatkowe koszty. Eksploatowanie pojazdów elektrycznych znacząco obniży wydatki na źródło energii do zasilania pojazdu, a także koszty serwisowe, ale powoduje ryzyko poniesienia istotnych kosztów wymiany akumulatorów gromadzących energię do napędu pojazdu.

Zwrócono uwagę, że wspieranie i promowanie wprowadzania nowych technologii do pojazdów samochodowych nie powinno być bezgraniczne i w zakresie automatyzacji samochodów niezwykle istotna jest rzetelna i jasno przekazana społeczeństwu informacja o aktualnych praktycznych możliwościach poszczególnych systemów wspomagania kierowcy.

\section{Bibliografia}

Bank Danych Lokalnych, www.stat.gov.pl [dostęp: 10.09.2018].

Eurostat, https://ec.europa.eu/eurostat/data/database [dostęp: 10.09.2018].

Handbook on estimation of external costs In the transport sector, CE Delft, February 2008.

Ntziachristos L. i in., COPERT: A European Road Transport Emission, Proceedings of the 4th International ICSC Symposium, Thessaloniki 2009.

Radzimirski S., Żółtowski A., Taubert S., Praca ITS Nr 7904: „Inwentaryzacja emisji wybranych zanieczyszczeń z sektora transportu drogowego w 2008 r.”. 
Radzimirski S., Żółtowski A., Taubert S., Praca ITS Nr 9139: „Inwentaryzacja emisji zanieczyszczeń z sektora transportu drogowego w 2004 r.”.

Update of the Handbook on External Costs of Transport, Ricardo-AEA, January 2014.

Wypadki drogowe w Polsce w 2017 roku, Komenda Główna Policji, Warszawa 2018.

\section{Streszczenie}

Rozwój gospodarczy z jednej strony jest realizowany w dużej mierze dzięki rozwojowi transportu drogowego poprzez wzrost pracy transportowej (w przypadku pojazdów użytkowych), z drugiej strony to właśnie rozwój gospodarczy umożliwia rozwój transportu drogowego dzięki rozwojowi technologii, przy jednoczesnym wzroście dochodów i oczekiwań społeczeństw. Te obustronne powiązania generują zarówno szanse, jak i zagrożenia dla środowiska i społeczeństwa płynące z rozwoju transportu drogowego.

Celem artykułujest zidentyfikowanie i przeanalizowanie szans i zagrożeń,jakie niesie ze sobą rozwój transportu drogowego dla środowiska i dla społeczeństwa. Analizie poddano zagadnienia związane $\mathrm{z}$ ochroną środowiska, uzupełniając je o zagadnienia techniczne oraz społeczne. Wskazano i przeanalizowano poszczególne aspekty w ramach tych zagadnień i każdorazowo zakwalifikowano je jako szansę bądź zagrożenie. Wyciągnięto wnioski dotyczące kierunku rozwoju transportu drogowego ze społecznego punktu widzenia przy uwzględnieniu zasad zrównoważonego rozwoju.

Słowa kluczowe: transport drogowy, ochrona środowiska, rozwój zrównoważony Numer klasyfikacji JEL: Q56, R41 